\title{
Anti-malarial effect of gum arabic
}

\author{
Adil Ballal ${ }^{1,2}$, Diwakar Bobbala', Syed M Qadri ${ }^{1}$, Michael Föller ${ }^{1}$, Daniela Kempe ${ }^{1}$, Omaima Nasir ${ }^{1}$, Amal Saeed ${ }^{2}$ and \\ Florian Lang ${ }^{1^{*}}$
}

\begin{abstract}
Background: Gum Arabic (GA), a nonabsorbable nutrient from the exudate of Acacia senegal, exerts a powerful immunomodulatory effect on dendritic cells, antigen-presenting cells involved in the initiation of both innate and adaptive immunity. On the other hand GA degradation delivers short chain fatty acids, which in turn have been shown to foster the expression of foetal haemoglobin in erythrocytes. Increased levels of erythrocyte foetal haemoglobin are known to impede the intraerythrocytic growth of Plasmodium and thus confer some protection against malaria. The present study tested whether gum arabic may influence the clinical course of malaria.
\end{abstract}

Methods: Human erythrocytes were in vitro infected with Plasmodium falciparum in the absence and presence of butyrate and mice were in vivo infected with Plasmodium berghei ANKA by injecting parasitized murine erythrocytes $\left(1 \times 10^{6}\right)$ intraperitoneally. Half of the mice received gum arabic (10\% in drinking water starting 10 days before the day of infection).

Results: According to the in vitro experiments butyrate significantly blunted parasitaemia only at concentrations much higher $(3 \mathrm{mM})$ than those encountered in vivo following GA ingestion $(<1 \mu \mathrm{M})$. According to the in vivo experiments the administration of gum arabic slightly but significantly decreased the parasitaemia and significantly extended the life span of infected mice.

Discussion: GA moderately influences the parasitaemia and survival of Plasmodium-infected mice. The underlying mechanism remained, however, elusive.

Conclusions: Gum arabic favourably influences the course of murine malaria.

\section{Background}

Gum Arabic (GA) from gummy exudates of Acacia Senegal [1] is a water-soluble [2] polysaccharide based on branched chains of (1-3) linked $\beta$-D-galactopyranosyl units containing $\alpha$-L-arabinofuranosyl, $\alpha$-L-rhamnopyranosyl, $\beta$-D-glucuronopyranosyl and 4-O-methyl- $\beta$-D-glucuronopyranosyl units [3]. It is considered one of the safest dietary fibers [4]. In Middle Eastern countries GA is employed in the treatment of patients with chronic renal disease and end stage renal failure [5]. Gum arabic increases the faecal nitrogen excretion [6] and decreases the production of free oxygen radicals [5].

Recent in vitro experiments revealed a powerful immunomodulary effect of GA on dendritic cells [7] antigen-presenting cells orchestrating the initiation of both innate and adaptive immunity and thus playing a

\footnotetext{
* Correspondence: florian.lang@uni-tuebingen.de

${ }^{1}$ Department of Physiology, University of Tübingen, Gmelinstr. 5, D-72076

Tübingen, Germany

Full list of author information is available at the end of the article
}

pivotal role in the regulation of the immune response [8-11].

The intestinal fermentation of gum arabic leads to the formation of several degradation products including shortchain fatty acids [6]. Accordingly, GA treatment may enhance the serum butyrate concentrations [12]. Butyrate compounds have been shown to up-regulate the formation of foetal haemoglobin [13-15], which may in turn confer some protection against a severe course of malaria [16-18]. Specifically, foetal haemoglobin has been shown to delay the haemoglobin degradation and thus to impede the intraerythrocyte growth of Plasmodium. Accordingly, expression of foetal haemoglobin protects against a severe course of malaria $[17,18]$.

Moreover, foetal haemoglobin may increase the susceptibility of foetal erythrocytes to oxidative stress [19]. As Plasmodium falciparum imposes oxidative stress on infected cells, it may trigger eryptosis, the suicidal death of erythrocytes [20,21]. Eryptosis is characterized by cell membrane scrambling with phosphatidylserine exposure
C Biomed Central

(c) 2011 Ballal et al; licensee BioMed Central Ltd. This is an Open Access article distributed under the terms of the Creative Commons Attribution License (http://creativecommons.org/licenses/by/2.0), which permits unrestricted use, distribution, and reproduction in any medium, provided the original work is properly cited. 
at the cell surface [22-26]. The cell membrane scrambling is triggered by increased cytosolic $\mathrm{Ca}^{2+}$ activity [23-27] and/or ceramide [28]. $\mathrm{Ca}^{2+}$ enters erythrocytes through $\mathrm{Ca}^{2+}$-permeable cation channels, which are activated by osmotic shock, oxidative stress or energy depletion [29-33]. In addition, $\mathrm{Ca}^{2+}$ stimulates $\mathrm{Ca}^{2+}$-sensitive $\mathrm{K}^{+}$channels [27,34,35], followed by cellular loss of $\mathrm{KCl}$ and osmotically obliged water leading to cell shrinkage [27]. The $\mathrm{Ca}^{2+}$-permeable cation channels are activated by oxidative stress [36], which thus stimulates eryptosis [37]. Excessive cytosolic $\mathrm{Ca}^{2+}$ concentrations stimulate similarly apoptosis of nucleated cells [38].

Phosphatidylserine-exposing cells are recognized $[39,40]$ and phagocytosed [41,42] by macrophages. Eryptotic cells are thus rapidly cleared from circulating blood [43]. The accelerated clearance of infected erythrocytes [44] may counteract the development of parasitaemia [45]. Enhanced susceptibility to eryptosis and accelerated clearance of Plasmodium-infected erythrocytes may confer relative protection against a severe course of malaria in carriers of sickle-cell trait, beta-thalassaemia-trait, homozygous $\mathrm{Hb}-\mathrm{C}$ and G6PD-deficiency [46-50], in iron deficiency [21], as well as during treatment with lead [20], chlorpromazine [51] and cyclosporine [52]. The erythrocyte cation channel is inhibited by erythropoietin [53], which may again influence the course of malaria [54].

The present study explored, whether gum arabic favourably influences parasitaemia and host survival during malaria.

\section{Methods}

Animal experiments were performed according to the German animal protection law and approved by the local authorities (registration number PY 2/06). Experiments were performed in healthy SV129/J wild type mice (aged 4 months, both male and female). The animals had free access to standard chow (ssniff, Soest, Germany) and drinking water. Murine erythrocytes were drawn from the animals by incision of the tail vein.

Human erythrocytes were drawn from healthy volunteers. The study was approved by the Ethical commission of the University of Tübingen.

In vitro experiments were performed at $37^{\circ} \mathrm{C}$ in Ringer solution containing (in $\mathrm{mM}$ ) $125 \mathrm{NaCl}, 5 \mathrm{KCl}, 1 \mathrm{MgSO}_{4}$, $32 \mathrm{~N}$-2-hydroxyethylpiperazine-N-2-ethanesulfonic acid (HEPES) $/ \mathrm{NaOH}$ (pH 7.4), 5 glucose, $1 \mathrm{CaCl}_{2}$ [55]. Butyrate was added to the $\mathrm{NaCl}$ Ringer at final concentrations varying from 0.3 to $10 \mathrm{mM}$ (Sigma, Schnelldorf, Germany). For in vitro treatment, the final haematocrit was adjusted to $0.3 \%$.

For determination of phosphatidylserine exposure, FACS analysis was performed as described [29]. After incubation in the presence or absence of gum arabic, suspensions of $P$. falciparum-infected erythrocytes were stained with annexin V-APC (BD Biosciences Pharmingen, Heidelberg, Germany) and/or with the DNA/RNA specific dye Syto16 (Molecular Probes, Göttingen, Germany) to identify phosphatidylserine-exposing and infected erythrocytes, respectively. For annexin V-binding, erythrocytes were washed, resuspended in annexin $\mathrm{V}$-binding buffer (Ringer solution containing $5 \mathrm{mM}$ $\mathrm{CaCl}_{2} \cdot \mathrm{pH}$ 7.4), stained with annexin V-APC (dilution 1:20), incubated for $20 \mathrm{~min}$ at room temperature, and diluted 1:5 with annexin V-binding buffer. Syto16 (final concentration of $20 \mathrm{nM}$ ) was added directly to the diluted erythrocyte suspension or co-incubated in the annexin V-binding buffer. Cells were analyzed by flow cytometry (FACS-Calibur, Becton Dickinson, Heidelberg, Germany) in fluorescence channel FL-1 for Syto16 (detected at $530 \mathrm{~nm}$ ) and in FL-4 for annexin V-APC fluorescence intensity (detected at $660 \mathrm{~nm}$ ).

For infection of human erythrocytes the human pathogen P. falciparum strain BinH [56] was grown in vitro [57]. Parasites were cultured as described earlier $[58,59]$ at a haematocrit of $2 \%$ and a parasitaemia of $2-10 \%$ in RPMI 1640 medium supplemented with Albumax II (0.5\%; Gibco, Karlsruhe, Germany) in an atmosphere of $90 \% \mathrm{~N}_{2}, 5 \% \mathrm{CO}_{2}, 5 \% \mathrm{O}_{2}[60,61]$.

For infection of mice Plasmodium berghei ANKAparasitized murine erythrocytes $\left(1 \times 10^{6}\right)$ were injected intraperitoneally $[62,63]$ into wildtype mice. Where indicated gum arabic ( $10 \%$ in drinking water) was administered starting 10 days before the day of infection. Blood was collected from the mice 8 days after infection by incision of the tail. Parasitaemia was determined by Syto-16 staining in FACS analysis.

To estimate the in vitro growth of $P$. falciparum, the BinH strain was cultured and synchronized to the ring stage by sorbitol treatment as described previously [36]. For the in vitro growth assay, synchronized parasitized erythrocytes were aliquoted in 96-well plates $(200 \mu \mathrm{l}$ aliquots, $1 \%$ haematocrit, $0.5-2 \%$ parasitaemia) and grown for $48 \mathrm{~h}$ in the presence or absence of butyrate $(0.3 \mathrm{mM}-10 \mathrm{mM})$. The parasitaemia was assessed at time 0 and after $48 \mathrm{~h}$ of culture by flow cytometry. Parasitaemia was defined by the percentage of erythrocytes stained with the DNA/RNA specific fluorescence dye Syto16.

To estimate DNA/RNA amplification of the intraerythrocytic parasite, the culture was ring stage-synchronized, and re-synchronized after $6 \mathrm{~h}$ of culture (to narrow the developmental parasite stage), aliquoted ( $200 \mu \mathrm{l}$ aliquots, $2 \%$ haematocrit and $10 \%$ parasitaemia) and cultured for further $16 \mathrm{~h}$ in the presence or absence of butyrate $(0.3 \mathrm{mM}$ $10 \mathrm{mM})$. Thereafter, the DNA/RNA amount of the parasitized erythrocytes was determined by Syto16 fluorescence as a measure of intraerythrocytic parasite copies.

Data are expressed as arithmetic means \pm SEM and statistical analysis was made by t-test or ANOVA using 
Tukey's test as post hoc test, as appropriate. $\mathrm{p}<0.05$ was considered as statistically significant. The mouse survival was analysed utilizing the Kaplan-Meier estimator method.

\section{Results}

According to a blood count, treatment with GA (10\% in drinking water) did not significantly affect blood parameters in non-infected mice (Table 1).

As treatment with GA is known to enhance plasma butyrate concentration, the influence of butyrate on the in vitro growth of the parasite was analysed. Plasmodium falciparum-infected erythrocytes were cultured in human erythrocytes and synchronized to ring stage by sorbitol treatment. Within 48 hours the percentage of infected erythrocytes increased from $5.09 \%$ to $17.82 \%$. In the presence of butyrate, the increase in the percentage of parasitized erythrocytes was decreased, an effect reaching statistical significance at $\geq 3 \mathrm{mM}$ butyrate concentration (Figure 1A). In contrast, the presence of butyrate did not show any significant decrease of the intraerythrocytic DNA amplification of the parasite (Figure 1B).

To determine the effect of infection and butyrate on suicidal erythrocyte death (eryptosis), the percentage of phosphatidylserine-exposing erythrocytes was estimated by measurement of annexin V-binding in FACS analysis. In vitro infection tended to increase the percentage of annexin V-binding erythrocytes (Figure $1 C$ ). The addition of butyrate tended to decrease the percentage of annexin V-binding cells, an effect, however, not reaching statistical significance (Figure 1C).

To determine the in vivo efficacy of gum arabic, mice were infected with $P$. berghei with or without GA treatment. Gum arabic (10\% in drinking water) was administered starting 10 days before the day of infection (Figure 2A). The percentage of infected erythrocytes gradually increased with or without gum arabic treatment. However, it was slightly lower in gum arabic-treated animals than in animals without gum arabic treatment, an effect reaching statistical significance throughout 10-21 days of infection (Figure 2B).

Infection with $P$. berghei significantly decreased the erythrocyte number per $\mu \mathrm{l}$, haematocrit (packed cell volume) and blood haemoglobin concentration (Table 1 ), effects all significantly blunted by treatment with GA (Table 1).

The infection was paralleled by triggering of cell membrane scrambling, as evidenced from annexin $\mathrm{V}$ binding (Figure 3). Irrespective of GA treatment, the percentage of annexin $\mathrm{V}$ binding cells was significantly higher in infected than in non-infected erythrocytes. The percentage of infected erythrocytes binding annexin $\mathrm{V}$ was higher in the GA-treated animals, an effect reaching statistical significance at day 19 of postinfection.

The treatment with GA further influenced the survival of $P$. berghei-infected mice. As shown in Figure 4, all untreated animals died within 26 days after the infection. In contrast, as many as $70 \%$ of the GA-treated animals survived the infection for more than 26 days.

\section{Discussion}

The present study reveals a completely novel effect of gum arabic, i.e. an influence on the course of malaria. Treatment with GA delayed a lethal course of malaria following infection of mice with $P$. berghei. As shown earlier, the infection of mice with $P$. berghei is followed by an invariably lethal course of malaria [62]. Treatment with GA did not prevent a lethal course of malaria but extended the survival of the infected animals. Accordingly, when all untreated animals had died, still more than half of the GA treated animals were alive.

The present observations do not allow safe conclusions as to the mechanisms underlying the moderate beneficial effect of GA treatment. Gum arabic treatment delayed the development of parasitaemia and blunted the decrease of blood erythrocyte number and haemoglobin concentration and thus significantly counteracted the development of anemia.

Table 1 Arithmetic means ( \pm SEM, $n=7$ ) of erythrocyte parameters of noninfected and infected mice without or with gum arabic treatment $(10 \%$ in drinking water)

\begin{tabular}{|c|c|c|c|c|}
\hline & \multicolumn{2}{|c|}{ Noninfected } & \multicolumn{2}{|c|}{ Infected } \\
\hline & $-G A$ & $+G A$ & $-G A$ & $+G A$ \\
\hline Erythrocyte number $\left(10^{6} / \mathrm{mm}^{3}\right)$ & $10.78 \pm 0.19$ & $11.03 \pm 0.10$ & $6.79 \pm 1.01^{\#, *}$ & $8.32 \pm 0.95^{\#, *}$ \\
\hline Haemoglobin (g/dl) & $15.57 \pm 0.32$ & $16.35 \pm 0.16$ & $9.47 \pm 1.38^{\#, *}$ & $11.77 \pm 1.39^{\#, *}$ \\
\hline Haematocrit (\%) & $43.34 \pm 0.32$ & $44.5 \pm 0.39$ & $28.27 \pm 4.3^{\#,{ }^{*}}$ & $34.31 \pm 3.72^{\#, *}$ \\
\hline Mean erythrocyte volume (MCV) (fl) & $40.2 \pm 0.38$ & $40.47 \pm 0.16$ & $41.35 \pm 0.63$ & $41.37 \pm 0.39$ \\
\hline Erythrocyte haemoglobin concentration (MCHC) (g/dl) & $35.91 \pm 0.20$ & $36.75 \pm 0.13$ & $33.88 \pm 0.55^{\#}$ & $34.04 \pm 0.49^{\#}$ \\
\hline §Haemoglobin/erythrocyte (pg) & $14.4 \pm 0.20$ & $14.88 \pm 0.07$ & $14.01 \pm 0.13$ & $14.07 \pm 0.10$ \\
\hline
\end{tabular}

$\S$ calculated from MCV and MCHC

* different from -GA

\# different from noninfected 


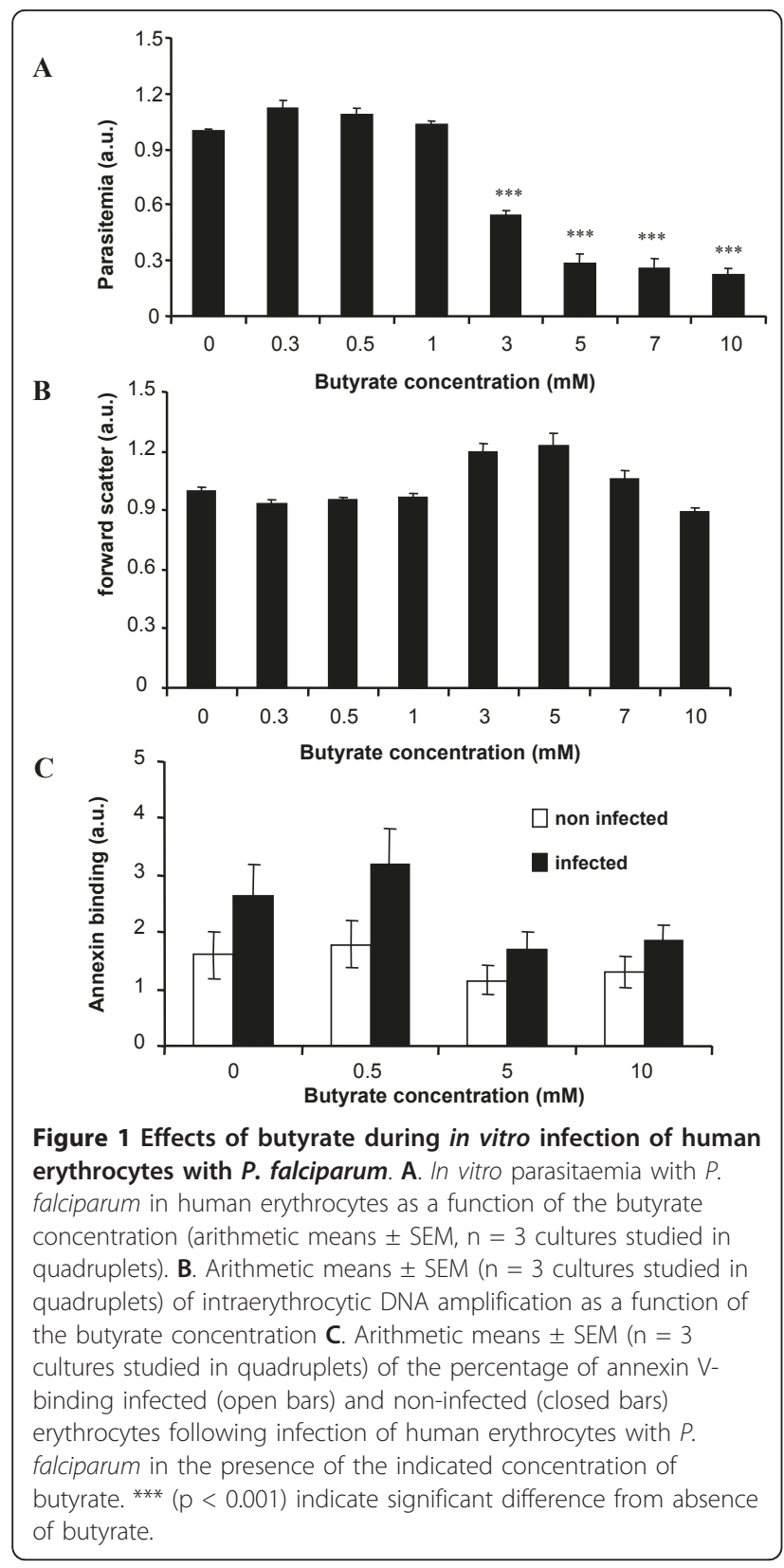

In theory, GA could affect parasitaemia and host survival by increasing the erythrocyte content of foetal haemoglobin, which is known to delay the intraerythrocytic growth of the parasite $[17,18]$. The effect would be apparent particularly following pretreatment of the mice with GA. While butyrate requires excessive concentrations to be effective in vitro, much lower concentrations could modify the formation of foetal hamoglobin [13-15] and thus susceptibility to malaria [16-18].

Foetal hemoglobin (HbF) has a higher $\mathrm{O}_{2}$ affinity than adult haemoglobin [64] and influences erythrocyte $\mathrm{K}^{+}$ transport and $\mathrm{O}_{2}$ dependence of erythrocyte glycolysis [65]. Increased $\mathrm{HbO}_{2}$ affinity may result in enhanced

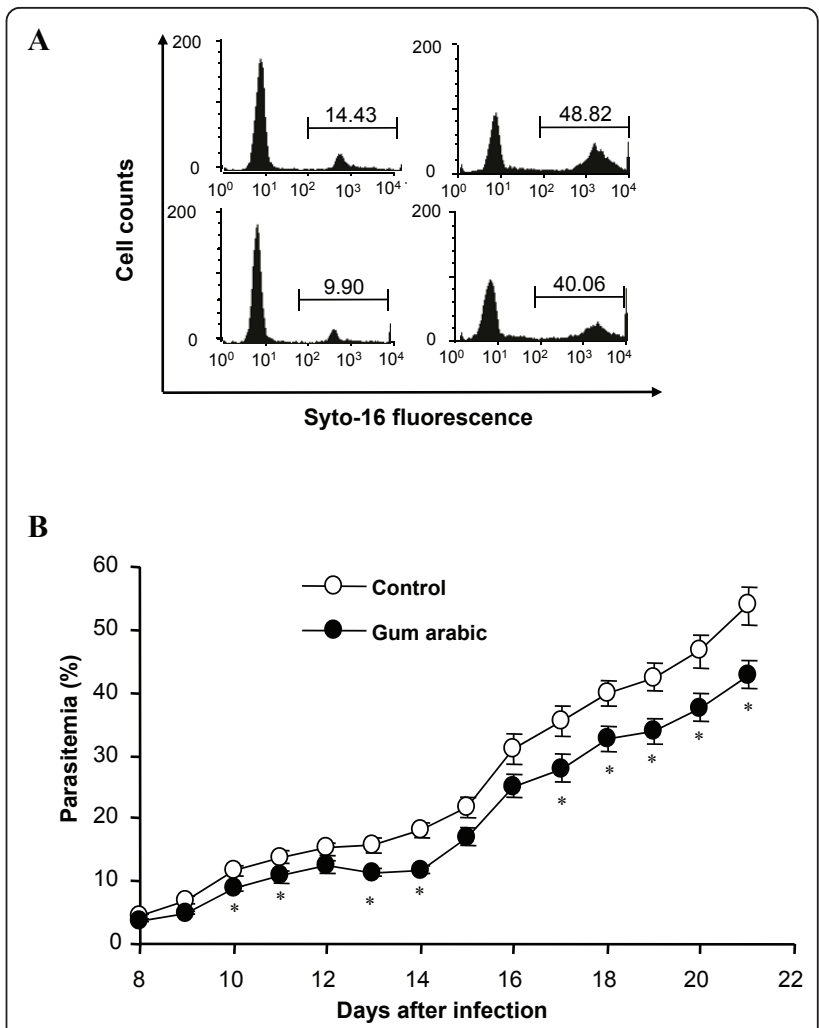

Figure 2 Effect of gum arabic treatment on parasitaemia of Plasmodium berghei-infected mice. A: Original histograms of parasitaemia-dependent Syto 16 fluorescence in untreated animals (upper panels) and animals treated from 10 days before infection until the day they survived with $10 \%$ gum arabic in drinking water (lower panels) 10 (left panels) and 20 (right panels) days after infection with $P$. berghei. B: Arithmetic means \pm SEM of parasitaemia in mice without treatment (open circles, $n=19$ ) or with $10 \%$ gum arabic in drinking water (closed circles, $n=17$ ) as a function of days after infection with $P$. berghei. * $(p \leq 0.05)$ indicates significant difference from untreated animals.

lactate formation with subsequent decrease of $\mathrm{HCO}_{3}{ }^{-}$ and thus increased $\mathrm{CO}_{2} / \mathrm{HCO}_{3}{ }^{-}$ratio. $\mathrm{CO}_{2}$ fosters SOD1 peroxidation, promoting the release of pro-inflammatory cytokines from activated macrophages leading to metabolic syndrome [66]. Those events may affect erythrocyte survival in parasitized erythrocytes.

Gum arabic, butyrate and/or foetal haemoglobin may affect parasitaemia and host survival by accelerating the suicidal death of infected erythrocytes [67]. Phosphatidylserine-exposing erythrocytes are phagocytosed [41,42] and thus rapidly cleared from circulating blood [43]. Eryptosis is triggered by a wide variety of substances [68-74]. Several of those substances have been shown to decrease parasitaemia and to extend the survival of infected mice [52,75-78]. Moreover, eryptosis is enhanced in several clinical conditions, such as iron deficiency [43], sickle-cell anaemia $[79,80]$, beta-thalassaemia [22], glucose-6-phosphate dehydrogenase (G6PD)-deficiency [22], 


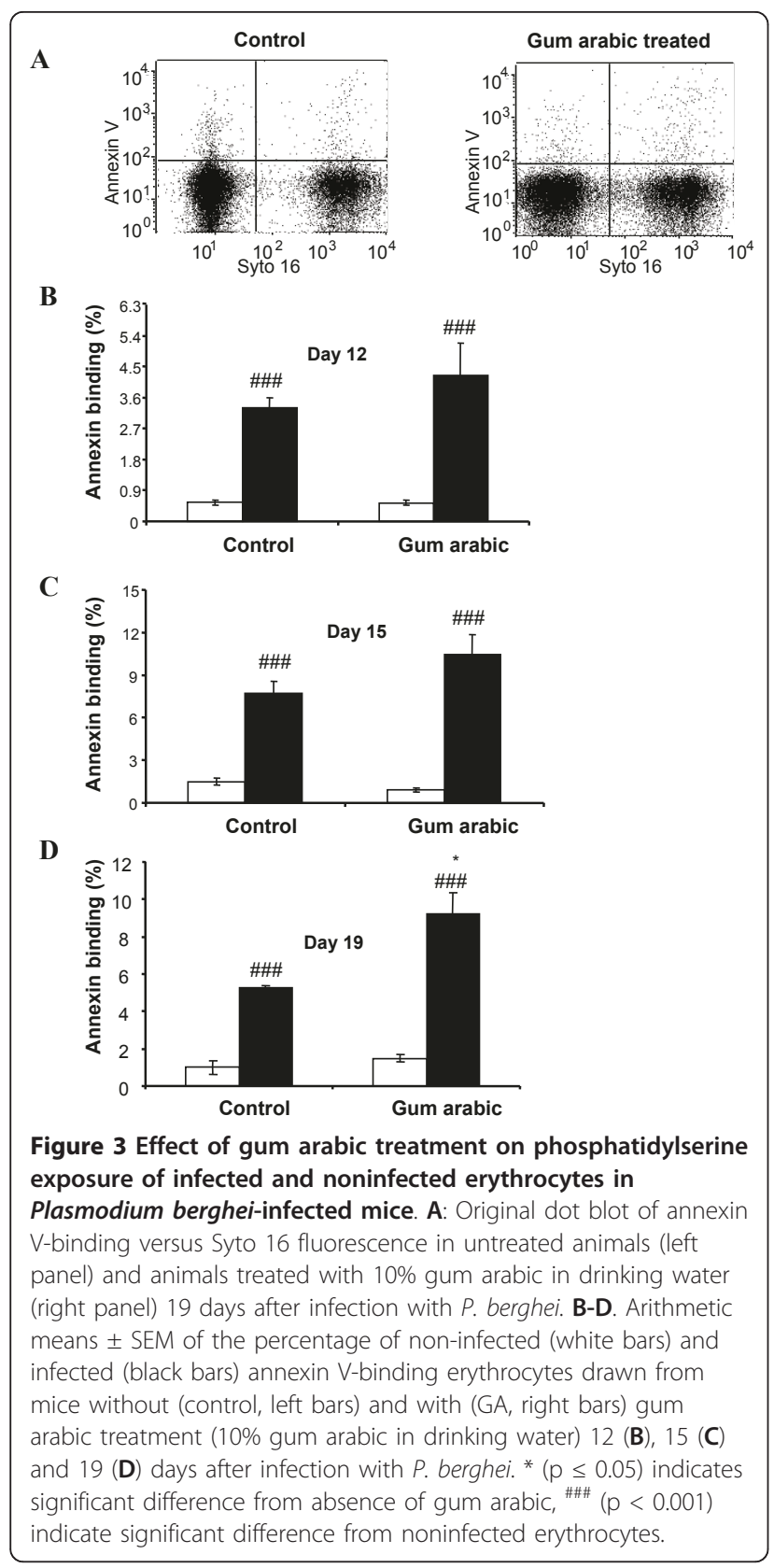

phosphate depletion [81], Haemolytic uremic syndrome [82], sepsis [83], malaria [45] and Wilson's disease [84]. Some of those diseases have similarly been shown to favourably influence the course of malaria, i.e. sickle-cell trait, beta-thalassaemia-trait, homozygous $\mathrm{Hb}-\mathrm{C}$ and G6PD-deficiency [22,46-50] as well as iron deficiency [21]. However, most of those diseases and substances exert a profound effect on parasitaemia.

In conclusion, in mice, gum arabic provides extended survival following the invariably lethal infection with $P$. berghei. Gum arabic is particularly effective in preventing an early death from this devastating disease.

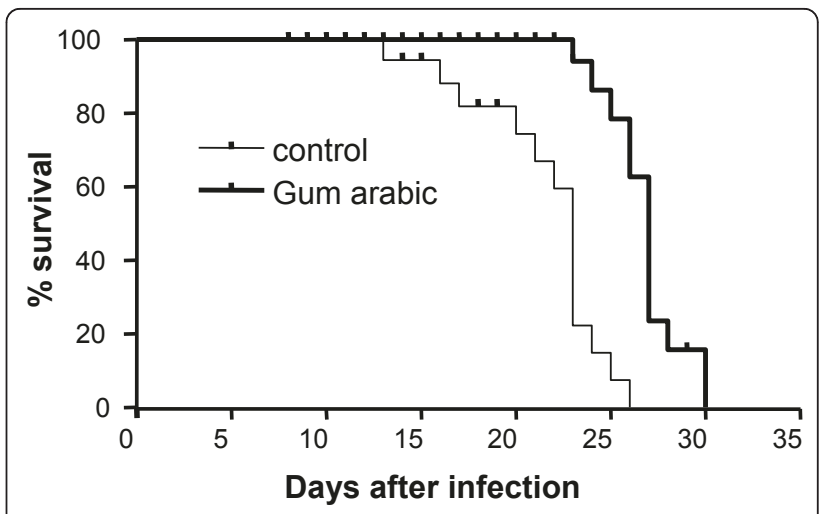

Figure 4 Effect of gum arabic treatment on survival of Plasmodium berghei infected mice. Survival of mice without treatment (light line) or with 10\% gum arabic in drinking water (dark line) as a function of days after infection with Plasmodium berghei. Gum arabic treatment significantly ( $p<0.0001$, Kaplan-Meier survival function test) enhances the survival of infected mice.

\section{Acknowledgements}

This study was supported by the Deutsche Forschungsgemeinschaft (La 315/ 6-1 and La 315/13-1). The authors acknowledge the meticulous preparation of the manuscript by Sari Rübe and Mara Koch.

\section{Author details}

${ }^{1}$ Department of Physiology, University of Tübingen, Gmelinstr. 5, D-72076 Tübingen, Germany. ${ }^{2}$ Department of Physiology, University of Khartoum, Elqasr Street, P.O.Box 102 Khartoum, Sudan.

\section{Authors' contributions}

$A B$ performed in vitro experiments, DB performed in vivo experiments, SMQ analysed eryptosis, MF evaluated the data and made the statistical analysis, DK supervised the in vivo experiments, ON initiated the study, AS initiated the gum arabic research and participated in the design, FL wrote the manuscript. All authors read and approved the final manuscript.

\section{Competing interests}

The authors declare that they have no competing interests.

Received: 22 February 2011 Accepted: 20 May 2011 Published: 20 May 2011

\section{References}

1. Younes H, Garleb K, Behr S, Remesy C, Demigne C: Fermentable fibers or oligosaccharides reduce urinary nitrogen excretion by increasing urea disposal in the rat cecum. J Nutr 1995, 125:1010-1016.

2. Tiss A, Carriere F, Verger R: Effects of gum arabic on lipase interfacial binding and activity. Anal Biochem 2001, 294:36-43.

3. Deckwer WD, Dill B, Eisenbrand E, Bornscheuer U, Pühler A, Heiker FR, Kirschning A, Schreier P, Fugmann B, Pohnert G: Römpp Online GeorgThieme-Verlag; 2006.

4. Anderson DM: Evidence for the safety of gum arabic (Acacia senegal (L.) Willd.) as a food additive-a brief review. Food Addit Contam 1986, 3:225-230.

5. Al Majed AA, Mostafa AM, Al Rikabi AC, Al Shabanah OA: Protective effects of oral arabic gum administration on gentamicin-induced nephrotoxicity in rats. Pharmacol Res 2002, 46:445-451.

6. Bliss DZ, Stein TP, Schleifer CR, Settle RG: Supplementation with gum arabic fiber increases fecal nitrogen excretion and lowers serum urea nitrogen concentration in chronic renal failure patients consuming a low-protein diet. Am J Clin Nutr 1996, 63:392-398.

7. Xuan NT, Shumilina E, Nasir O, Bobbala D, Gotz F, Lang F: Stimulation of mouse dendritic cells by Gum Arabic. Cell Physiol Biochem 2010, 25:641-648. 
8. Adler HS, Steinbrink K: Tolerogenic dendritic cells in health and disease: friend and foe! Eur J Dermatol 2007, 17:476-491.

9. Banchereau J, Briere F, Caux C, Davoust J, Lebecque S, Liu YJ, Pulendran B, Palucka K: Immunobiology of dendritic cells. Annu Rev Immunol 2000, 18:767-811.

10. Steinman RM, Nussenzweig MC: Avoiding horror autotoxicus: the importance of dendritic cells in peripheral T cell tolerance. Proc Natl Acad Sci USA 2002, 99:351-358.

11. van Duivenvoorde LM, Han WG, Bakker AM, Louis-Plence P, Charbonnier LM, Apparailly F, van der Voort El, Jorgensen C, Huizinga TW, Toes RE: Immunomodulatory dendritic cells inhibit Th1 responses and arthritis via different mechanisms. J Immunol 2007, 179:1506-1515.

12. Matsumoto N, Riley S, Fraser D, Al Assaf S, Ishimura E, Wolever T, Phillips GO, Phillips AO: Butyrate modulates TGF-beta1 generation and function: potential renal benefit for Acacia(sen) SUPERGUM (gum arabic)? Kidney Int 2006, 69:257-265.

13. Goren A, Simchen G, Fibach E, Szabo PE, Tanimoto K, Chakalova L, Pfeifer GP, Fraser PJ, Engel JD, Cedar H: Fine tuning of globin gene expression by DNA methylation. PLoS One 2006, 1:e46.

14. Mankidy R, Faller DV, Mabaera R, Lowrey CH, Boosalis MS, White GL, Castaneda SA, Perrine SP: Short-chain fatty acids induce gamma-globin gene expression by displacement of a HDAC3-NCoR repressor complex. Blood 2006, 108:3179-3186.

15. Perrine SP, Ginder GD, Faller DV, Dover GH, Ikuta T, Witkowska HE, Cai SP, Vichinsky EP, Olivieri NF: A short-term trial of butyrate to stimulate fetalglobin-gene expression in the beta-globin disorders. N Engl J Med 1993, 328:81-86.

16. Pasvol G, Weatherall DJ, Wilson RJ, Smith DH, Gilles HM: Fetal haemoglobin and malaria. Lancet 1976, 1:1269-1272.

17. Pasvol G, Weatherall DJ, Wilson RJ: Effects of foetal haemoglobin on susceptibility of red cells to Plasmodium falciparum. Nature 1977, 270:171-173.

18. Shear HL, Grinberg L, Gilman J, Fabry ME, Stamatoyannopoulos G, Goldberg DE, Nagel RL: Transgenic mice expressing human fetal globin are protected from malaria by a novel mechanism. Blood 1998, 92:2520-2526.

19. Hermle T, Shumilina E, Attanasio P, Akel A, Kempe DS, Lang PA, Podolski M, Gatz S, Bachmann R, Bachmann C, Abele H, Huber S, Wieder T, Lang F: Decreased cation channel activity and blunted channel-dependent eryptosis in neonatal erythrocytes. Am J Physiol Cell Physiol 2006, 291: C710-C717.

20. Koka S, Huber SM, Boini KM, Lang C, Foller M, Lang F: Lead decreases parasitemia and enhances survival of Plasmodium berghei-infected mice. Biochem Biophys Res Commun 2007, 363:484-489.

21. Koka S, Foller M, Lamprecht G, Boini KM, Lang C, Huber SM, Lang F: Iron deficiency influences the course of malaria in Plasmodium berghei infected mice. Biochem Biophys Res Commun 2007, 357:608-614.

22. Lang KS, Roll B, Myssina S, Schittenhelm M, Scheel-Walter HG, Kanz L, Fritz J, Lang F, Huber SM, Wieder T: Enhanced erythrocyte apoptosis in sickle cell anemia, thalassemia and glucose-6-phosphate dehydrogenase deficiency. Cell Physiol Biochem 2002, 12:365-372.

23. Berg CP, Engels IH, Rothbart A, Lauber K, Renz A, Schlosser SF, SchulzeOsthoff K, Wesselborg S: Human mature red blood cells express caspase3 and caspase-8, but are devoid of mitochondrial regulators of apoptosis. Cell Death Differ 2001, 8:1197-1206.

24. Brand VB, Sandu CD, Duranton C, Tanneur V, Lang KS, Huber SM, Lang F: Dependence of Plasmodium falciparum in vitro growth on the cation permeability of the human host erythrocyte. Cell Physiol Biochem 2003, 13:347-356.

25. Bratosin D, Estaquier J, Petit F, Arnoult D, Quatannens B, Tissier JP, Slomianny C, Sartiaux C, Alonso C, Huart JJ, Montreuil J, Ameisen JC: Programmed cell death in mature erythrocytes: a model for investigating death effector pathways operating in the absence of mitochondria. Cell Death Differ 2001, 8:1143-1156.

26. Daugas E, Cande C, Kroemer G: Erythrocytes: death of a mummy. Cell Death Differ 2001, 8:1131-1133.

27. Lang PA, Kaiser S, Myssina S, Wieder T, Lang F, Huber SM: Role of Ca2 +-activated $\mathrm{K}+$ channels in human erythrocyte apoptosis. Am J Physiol Cell Physiol 2003, 285:C1553-C1560.

28. Lang KS, Myssina S, Brand V, Sandu C, Lang PA, Berchtold S, Huber SM, Lang F, Wieder T: Involvement of ceramide in hyperosmotic shockinduced death of erythrocytes. Cell Death Differ 2004, 11:231-243.
29. Lang KS, Duranton C, Poehlmann H, Myssina S, Bauer C, Lang F, Wieder T, Huber SM: Cation channels trigger apoptotic death of erythrocytes. Cell Death Differ 2003, 10:249-256.

30. Bernhardt I, Weiss E, Robinson HC, Wilkins R, Bennekou P: Differential effect of HOE642 on two separate monovalent cation transporters in the human red cell membrane. Cell Physiol Biochem 2007, 20:601-606.

31. Duranton C, Huber SM, Lang F: Oxidation induces a Cl(-)-dependent cation conductance in human red blood cells. J Physiol 2002, 539:847-855.

32. Foller M, Kasinathan RS, Koka S, Lang C, Shumilina E, Birnbaumer L, Lang F, Huber SM: TRPC6 contributes to the $\mathrm{Ca}(2+)$ leak of human erythrocytes. Cell Physiol Biochem 2008, 21:183-192.

33. Huber SM, Gamper N, Lang F: Chloride conductance and volumeregulatory nonselective cation conductance in human red blood cell ghosts. Pflugers Arch 2001, 441:551-558.

34. Bookchin RM, Ortiz OE, Lew VL: Activation of calcium-dependent potassium channels in deoxygenated sickled red cells. Prog Clin Biol Res 1987, 240:193-200.

35. Brugnara C, de Franceschi L, Alper SL: Inhibition of Ca(2+)-dependent K+ transport and cell dehydration in sickle erythrocytes by clotrimazole and other imidazole derivatives. J Clin Invest 1993, 92:520-526.

36. Duranton C, Huber S, Tanneur V, Lang K, Brand V, Sandu C, Lang F: Electrophysiological properties of the Plasmodium falciparum-induced cation conductance of human erythrocytes. Cell Physiol Biochem 2003, 13:189-198.

37. Tyurina YY, Tyurin VA, Zhao Q, Djukic M, Quinn PJ, Pitt BR, Kagan VE: Oxidation of phosphatidylserine: a mechanism for plasma membrane phospholipid scrambling during apoptosis? Biochem Biophys Res Commun 2004, 324:1059-1064.

38. McConkey DJ, Orrenius S: The role of calcium in the regulation of apoptosis. Biochem Biophys Res Commun 1997, 239:357-366.

39. Fadok VA, Bratton DL, Rose DM, Pearson A, Ezekewitz RA, Henson PM: A receptor for phosphatidylserine-specific clearance of apoptotic cells. Nature 2000, 405:85-90.

40. Henson PM, Bratton DL, Fadok VA: The phosphatidylserine receptor: a crucial molecular switch? Nat Rev Mol Cell Biol 2001, 2:627-633.

41. Boas FE, Forman L, Beutler E: Phosphatidylserine exposure and red cell viability in red cell aging and in hemolytic anemia. Proc Natl Acad Sci USA 1998, 95:3077-3081.

42. Yamanaka M, Eda S, Beppu M: Carbohydrate chains and phosphatidylserine successively work as signals for apoptotic cell removal. Biochem Biophys Res Commun 2005, 328:273-280.

43. Kempe DS, Lang PA, Duranton C, Akel A, Lang KS, Huber SM, Wieder T, Lang F: Enhanced programmed cell death of iron-deficient erythrocytes. FASEB J 2006, 20:368-370.

44. Schwarzer E, Turrini F, Ulliers D, Giribaldi G, Ginsburg H, Arese P: Impairment of macrophage functions after ingestion of Plasmodium falciparum-infected erythrocytes or isolated malarial pigment. J Exp Med 1992, 176:1033-1041.

45. Lang F, Lang PA, Lang KS, Brand V, Tanneur V, Duranton C, Wieder T, Huber SM: Channel-induced apoptosis of infected host cells-the case of malaria. Pflugers Arch 2004, 448:319-324.

46. Ayi K, Turrini F, Piga A, Arese P: Enhanced phagocytosis of ring-parasitized mutant erythrocytes: a common mechanism that may explain protection against falciparum malaria in sickle trait and beta-thalassemia trait. Blood 2004, 104:3364-3371.

47. Cappadoro M, Giribaldi G, O'Brien E, Turrini F, Mannu F, Ulliers D, Simula G, Luzzatto L, Arese P: Early phagocytosis of glucose-6-phosphate dehydrogenase (G6PD)-deficient erythrocytes parasitized by Plasmodium falciparum may explain malaria protection in G6PD deficiency. Blood 1998, 92:2527-2534.

48. de Jong K, Emerson RK, Butler J, Bastacky J, Mohandas N, Kuypers FA: Short survival of phosphatidylserine-exposing red blood cells in murine sickle cell anemia. Blood 2001, 98:1577-1584.

49. Kean LS, Brown LE, Nichols JW, Mohandas N, Archer DR, Hsu LL: Comparison of mechanisms of anemia in mice with sickle cell disease and beta-thalassemia: peripheral destruction, ineffective erythropoiesis, and phospholipid scramblase-mediated phosphatidylserine exposure. Exp Hematol 2002, 30:394-402.

50. Kuypers FA, Yuan J, Lewis RA, Snyder LM, Kiefer CR, Bunyaratvej A, Fucharoen S, Ma L, Styles L, de Jong K, Schrier SL: Membrane 
phospholipid asymmetry in human thalassemia. Blood 1998, 91:3044-3051.

51. Koka S, Lang C, Boini KM, Bobbala D, Huber SM, Lang F: Influence of chlorpromazine on eryptosis, parasitemia and survival of Plasmodium berghei-infected mice. Cell Physiol Biochem 2008, 22:261-268.

52. Bobbala D, Alesutan I, Foller M, Huber SM, Lang F: Effect of anandamide in Plasmodium berghei-infected mice. Cell Physiol Biochem 2010, 26:355-362.

53. Myssina S, Huber SM, Birka C, Lang PA, Lang KS, Friedrich B, Risler T, Wieder T, Lang F: Inhibition of erythrocyte cation channels by erythropoietin. J Am Soc Nephrol 2003, 14:2750-2757.

54. Wiese L, Hempel C, Penkowa M, Kirkby N, Kurtzhals JA: Recombinant human erythropoietin increases survival and reduces neuronal apoptosis in a murine model of cerebral malaria. Malar J 2008, 7:3.

55. Duranton C, Tanneur V, Lang C, Brand VB, Koka S, Kasinathan RS, Dorsch M, Hedrich HJ, Baumeister S, Lingelbach K, Lang F, Huber SM: A high specificity and affinity interaction with serum albumin stimulates an anion conductance in malaria-infected erythrocytes. Cell Physiol Biochem 2008, 22:395-404.

56. Binh VQ, Luty AJ, Kremsner PG: Differential effects of human serum and cells on the growth of Plasmodium falciparum adapted to serum-free in vitro culture conditions. Am J Trop Med Hyg 1997, 57:594-600.

57. Huber SM, Uhlemann AC, Gamper NL, Duranton C, Kremsner PG, Lang F: Plasmodium falciparum activates endogenous $\mathrm{Cl}(-)$ channels of human erythrocytes by membrane oxidation. EMBO J 2002, 21:22-30.

58. Jensen JB, Trager W: Plasmodium falciparum in culture: establishment of additional strains. Am J Trop Med Hyg 1978, 27:743-746.

59. Trager W, Jensen JB: Human malaria parasites in continuous culture. Science 1976, 193:673-675.

60. Brand VB, Koka S, Lang C, Jendrossek V, Huber SM, Gulbins E, Lang F: Influence of amitriptyline on eryptosis, parasitemia and survival of Plasmodium berghei-infected mice. Cell Physiol Biochem 2008, 22:405-412.

61. Koka S, Lang C, Niemoeller OM, Boini KM, Nicolay JP, Huber SM, Lang F: Influence of NO synthase inhibitor L-NAME on parasitemia and survival of Plasmodium berghei infected mice. Cell Physiol Biochem 2008, 21:481-488.

62. Huber SM, Duranton C, Henke G, Van De SC, Heussler V, Shumilina E, Sandu CD, Tanneur V, Brand V, Kasinathan RS, Lang KS, Kremsner PG, Hubner CA, Rust MB, Dedek K, Jentsch TJ, Lang F: Plasmodium induces swelling-activated CIC-2 anion channels in the host erythrocyte. J Biol Chem 2004, 279:41444-41452.

63. Lackner P, Hametner C, Beer R, Burger C, Broessner G, Helbok R, Speth C, Schmutzhard E: Complement factors $\mathrm{C} 1 \mathrm{q}, \mathrm{C} 3$ and $\mathrm{C} 5$ in brain and serum of mice with cerebral malaria. Malar J 2008, 7:207.

64. Bursaux E, Poyart C, Guesnon P, Teisseire B: Comparative effects of $\mathrm{CO} 2$ on the affinity for $\mathrm{O} 2$ of fetal and adult erythrocytes. Pflugers Arch 1979, 378:197-203.

65. Weber RE: Lacking deoxygenation-linked interaction between cytoplasmic domain of band 3 and $\mathrm{HbF}$ from fetal red blood cells. Acta Physiol (Oxf) 2007, 191:247-252.

66. Zappulla D: Environmental stress, erythrocyte dysfunctions, inflammation, and the metabolic syndrome: adaptations to $\mathrm{CO} 2$ increases? J Cardiometab Syndr 2008, 3:30-34.

67. Geiger C, Foller M, Herrlinger KR, Lang F: Azathioprine-induced suicidal erythrocyte death. Inflamm Bowel Dis 2008, 14:1027-1032.

68. Lang F, Gulbins E, Lerche H, Huber SM, Kempe DS, Foller M: Eryptosis, a window to systemic disease. Cell Physiol Biochem 2008, 22:373-380

69. Bhavsar SK, Bobbala D, Xuan NT, Foller M, Lang F: Stimulation of suicidal erythrocyte death by alpha-lipoic acid. Cell Physiol Biochem 2010, 26:859-868.

70. Bhavsar SK, Eberhard M, Bobbala D, Lang F: Monensin induced suicidal erythrocyte death. Cell Physiol Biochem 2010, 25:745-752.

71. Eberhard M, Ferlinz K, Alizzi K, Cacciato PM, Faggio C, Foller M, Lang F: FTY720-induced suicidal erythrocyte death. Cell Physiol Biochem 2010, 26:761-766.

72. Lang F, Gulbins E, Lang PA, Zappulla D, Foller M: Ceramide in suicidal death of erythrocytes. Cell Physiol Biochem 2010, 26:21-28.

73. Mahmud H, Mauro D, Qadri SM, Foller M, Lang F: Triggering of suicidal erythrocyte death by amphotericin B. Cell Physiol Biochem 2009, 24:263-270.
74. Mahmud H, Dalken B, Wels WS: Induction of programmed cell death in ErbB2/HER2-expressing cancer cells by targeted delivery of apoptosisinducing factor. Mol Cancer Ther 2009, 8:1526-1535.

75. Foller M, Bobbala D, Koka S, Huber SM, Gulbins E, Lang F: Suicide for survival-death of infected erythrocytes as a host mechanism to survive malaria. Cell Physiol Biochem 2009, 24:133-140.

76. Koka S, Bobbala D, Lang C, Boini KM, Huber SM, Lang F: Influence of paclitaxel on parasitemia and survival of Plasmodium berghei infected mice. Cell Physiol Biochem 2009, 23:191-198.

77. Lang PA, Kasinathan RS, Brand VB, Duranton C, Lang C, Koka S, Shumilina E, Kempe DS, Tanneur V, Akel A, Lang KS, Foller M, Kun JF, Kremsner PG, Wesselborg S, Laufer S, Clemen CS, Herr C, Noegel AA, Wieder T, Gulbins E, Lang F, Huber SM: Accelerated clearance of Plasmodium-infected erythrocytes in sickle cell trait and annexin-A7 deficiency. Cell Physiol Biochem 2009, 24:415-428.

78. Siraskar B, Ballal A, Bobbala D, Foller M, Lang F: Effect of amphotericin B on parasitemia and survival of Plasmodium berghei-infected mice. Cell Physiol Biochem 2010, 26:347-354.

79. Hebbel RP: Beyond hemoglobin polymerization: the red blood cell membrane and sickle disease pathophysiology. Blood 1991, 77:214-237.

80. Wood BL, Gibson DF, Tait JF: Increased erythrocyte phosphatidylserine exposure in sickle cell disease: flow-cytometric measurement and clinical associations. Blood 1996, 88:1873-1880.

81. Birka C, Lang PA, Kempe DS, Hoefling L, Tanneur V, Duranton C, Nammi S, Henke G, Myssina S, Krikov M, Huber SM, Wieder T, Lang F: Enhanced susceptibility to erythrocyte "apoptosis" following phosphate depletion. Pflugers Arch 2004, 448:471-477.

82. Lang PA, Beringer O, Nicolay JP, Amon O, Kempe DS, Hermle T, Attanasio P, Akel A, Schafer R, Friedrich B, Risler T, Baur M, Olbricht CJ, Zimmerhackl LB, Zipfel PF, Wieder T, Lang F: Suicidal death of erythrocytes in recurrent hemolytic uremic syndrome. J Mol Med 2006, 84:378-388.

83. Kempe DS, Akel A, Lang PA, Hermle T, Biswas R, Muresanu J, Friedrich B, Dreischer P, Wolz C, Schumacher U, Peschel A, Gotz F, Doring G, Wieder T, Gulbins E, Lang F: Suicidal erythrocyte death in sepsis. J Mol Med 2007, 85:269-277.

84. Lang PA, Kaiser S, Myssina S, Birka C, Weinstock C, Northoff H, Wieder T, Lang F, Huber SM: Effect of Vibrio parahaemolyticus haemolysin on human erythrocytes. Cell Microbiol 2004, 6:391-400.

doi:10.1186/1475-2875-10-139

Cite this article as: Ballal et al.: Anti-malarial effect of gum arabic. Malaria Journal 2011 10:139.

\section{Submit your next manuscript to BioMed Central and take full advantage of:}

- Convenient online submission

- Thorough peer review

- No space constraints or color figure charges

- Immediate publication on acceptance

- Inclusion in PubMed, CAS, Scopus and Google Scholar

- Research which is freely available for redistribution

Submit your manuscript at www.biomedcentral.com/submit
C Biomed Central 